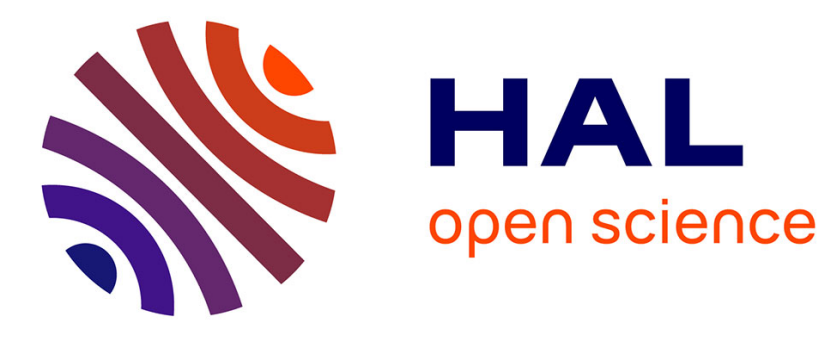

\title{
Railways and demographic change
}

Nacima Baron

\section{To cite this version:}

Nacima Baron. Railways and demographic change. Matthias Finger, Pierre Messulam. Rail economics, policy and regulation in Europe, Edward Elgar Publishing , pp.22-37, 2015. hal-01310515

\section{HAL Id: hal-01310515 \\ https://hal.science/hal-01310515}

Submitted on 2 May 2016

HAL is a multi-disciplinary open access archive for the deposit and dissemination of scientific research documents, whether they are published or not. The documents may come from teaching and research institutions in France or abroad, or from public or private research centers.
L'archive ouverte pluridisciplinaire HAL, est destinée au dépôt et à la diffusion de documents scientifiques de niveau recherche, publiés ou non, émanant des établissements d'enseignement et de recherche français ou étrangers, des laboratoires publics ou privés. 


\title{
Chapter 2: Railways and demographic change
}

\author{
Professor N. Baron \\ Université Paris Est \\ nbaron@univ-mlv.fr
}

\section{Introduction}

An attempt to understand the interactions between the spread of railways and the dynamics of settlement, demographic change and urban growth is part of a body of research that has a long history. Few researchers have summarised this researchin termsas straightforward as those of the geographer Pierre George, who wrote, in 1968: 'The layoutof the railway network determines the rates of growth of cities [page 233]'. This statement, while obviously simplistic, provides us with a possible starting point as it refers to the more or less general belief that a technological systemsuch as the train encourages the population to group together and, hence, provides an impetus for trade flows, and hence business activities and wealth (Ribeill, 1986). ${ }^{1}$

As this George's idea has determined the nature of this field of research, and is part of a long intellectual tradition, the first part of this chapter sets out to highlight not itsthe truth of the statement, but rather its continual presence during different phases of history or, to use David Banister's expression, during the different ages of the train(Banister and Hall, 1993). We will then present the mechanisms of interaction between the rail network and demographic dynamics, before explaining how demographic changes have affected the overall performance of the European rail system.

\section{The railway network and urban growth: a constant factor in geographical thought}

\subsection{Correlation between the network construction and the urban changes of the nineteenth century}

When making his simple statement, Pierre George was speaking in the tradition of nineteenth-century engineers who attempted to optimise the location of the branches of the railway network on the basis of geographical criteria. For example, in 1863 the civil engineer LéonLalanne presented the Académie des Sciences with a design rule that exploiteddensity measurements of towns and villages, along with calculations of their distance from centres in 
order to establishwhat he referred to as ademographicallybased 'theory of railways' (Lalanne, 1863). Another civil engineer, Charles-Joseph Minard (see Figure 1) provided maps that showed the clear spatial connections between urbanisation and the railway network(Friendly M. 2002, Robinson AH, 1967).Therefore, Minard's maps do not show the lines themselves, but the relative size of the passenger flows on each line. This proves that contemporaries were aware that urban growth was taking place at the same time as, andin interaction with,strong industrial development, human migration (from the countryside into the cities, but also from one city to another) and the extension of the railway network.

\section{PLEASE ADD A FRAME WITH MAP AND FOLLOWING CAPTION}

Figure 1 European Railways Passenger's flows in Europe in 1862

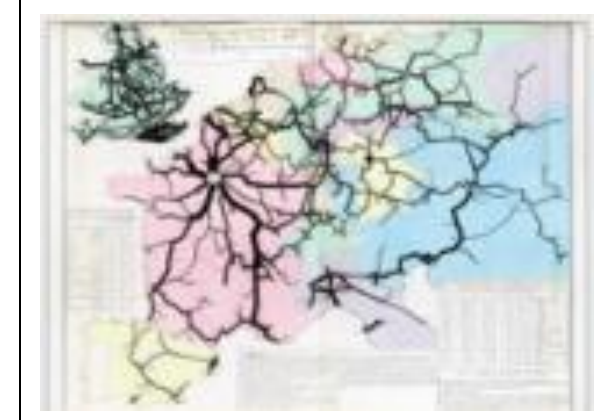

Source: From the collection of ancient documents in the EcoleNationale des Ponts et Chaussées Reference Number FOL 10975.

Charles-Joseph Minard is a relatively unknown civil engineer who was involved in the construction of the French railway network, and a pioneer of statistical and thematic cartography. His map of passenger movements on European railway lines was based on passenger data from 1862, which he himself collated and put in a comprehensible visual form: the width of the lines is strictly proportional to the relative numbers of passengers, and the scales and coastlines have been distorted, according to the principle of cartographic generalisation, without interfering with comprehension. While the empires and borders have changed a great deal in central and eastern Europe (for example, in Germany and the former Austro-Hungarian empire), thereby altering the relative importance of cities and the direction of flows, the radial structure of the French railway system and the density of communications in Great Britain and the Benelux countries has not changed enormously: 150 years later, in 2014 it is almost possible to superimpose Minard's map and a map of passenger flows on HSR lines west of the Rhine. 


\subsection{When the railway network and the network of cities form a single entity: territorial modelsand regional typologies on the threshold of the 1960s}

If we now move a century forward, to the time during which Pierre Georgemade his statement, the point at issue was not so much to build new lines, as the European network was considered to be 'mature', but to modernise the railway system in order to adapt to a new economic and demographic situation. The rural exodus was petering out, and cities were diversifying their industrial and service bases. Consequently,Pierre Georgemeant something different by the term 'urban growth'thanLalanne orMinard did. He was no longer attempting to optimise the design of the network in relation to a given pattern of human settlement, nor was he seeking to provide the best possible services between mining areas and industrial centres. In the 1960s, the car was already providing stiff competition for passenger rail services, and lorries were transporting a growing proportion of freight traffic. Consequently,what was at stakein the interaction between railways and demographic change was regional planning. The idea was to allow the rail system to give structure toan efficient network of cities that would act as regional centres, create growth and attract a young, qualified and skilled workforce.

Pierre George's research was therefore concerned with the link between demographic change, the network of cities and the railway system, with a view to creatingan 'urban backbone'that would fulfil the role of wealth creation with varying degrees of success (Juillard, 1971). This research was very much influenced by an updated form of central place theory that was known by the name of 'regional science', and which generated models that explained the effects of the network on the urban system and human settlement.Among the research conducted during this period, studies that examined'the demography of railway networks' (Chatelain, 1947)highlighted the success of some cities and the failure of others as a result of traffic conditions, service frequencies, passenger numbers and the economic specialisation of different areas.

\subsection{High-speed rail's re-organisation of the network of cities}

There was something of a hiatus in scientific output between the 1960s and the advent of a third phase of research, which went together with the third age of the train, namely highspeed rail (HSR), and the third urban age, that of the globalised metropolis (Claval, 2000). In this new phase, the shortening of journey times, the deindustrialisation of cities, the digital revolution and the globalisation of the economy workedtogether with demographic 
changesand, for a number of reasons, led to the adoption of a radically different approach to the issue. First, the high-speed network marked out some parts of the country from the remaining network of cities, thereby creating preferential accessibility conditions between (frequently large) cities and omitting those cities that lie between them(the so-called tunnel effect) (Hall and Banister, 2013). HSR is also responsible for a change in commuting patterns and leisure travel (Dieleman and Faludi, 1998).

Thus, the three historical phases we have proposed provide us with a useful analysis framework, as they show the holistic nature of the human, urban and economic changes that have gripped the European continent since the middle of the nineteenth century, and the way in which rail can be seen as both a product of these changes, and a factor that has accelerated them (Labasse, 1945). The train in itself has not directly set in motion or affected any demographic events, nor triggeredexnihiloany processes of urbanisation, but it has intensified or impeded broader mechanisms which, when analysed, reveal the singular nature of the regional profiles in question. This also shows that the interactions involved are highly diverse, as are the scientific approaches to their study,which depend on the nature and goals of research and the socioeconomic context (Jensen and Richarson, 2007)

\section{Retrospective analysis of the interactions between railways, human flows and urbanisation from 1830 s to the dawn of the 21 st century}

\subsection{What is the point of a retrospective analysis?}

Some readers may doubt the value of studying past interactions between demographic change and railways. How, for example, does an explanation of the way the railway network emptied the large agricultural estates of eastern Prussiahelp us understand the rail strategies implemented today? In our view, operators frequently make the mistake of considering demographic factors as an externality (Accenture, 2010), in the same terms as the main environmental or energy-related issues. However, the history of the location of settlement is an internality, as the railway network has been, to a large extent, inherited from earlier phases of the interaction between settlement, geography and the economy. Comparing the settlement modelin relation to models of the entire European railway network, and considering with equanimity the issue of the 'path dependency'generated by the excessive provision of railways in the first half of the twentieth century may prove useful in making us aware of issues that are very much of current concern (Merger and Polino, 2004). 


\subsection{What we know about the interactions between the rail network and settlement}

Few studies haveanalysed demographic change and change in the rail network at European level since the creation of the latter (Martí-Henneberg, 2013; O'Brien, 1983), which contrasts with the situation relating tothe creation of each country's network (Caron, 2005; Cobb, 2003; del Río et al., 2008; Turnock, 1998; Schram, 1997; Silveira et al., 2011). Nevertheless, irrespective of where the focus is placed, research in this area potentially targets two different goals. The first is to discuss what rail owes to demography and what it does not; that is,to seehow well, or how badly, the geographical distribution of the population matched the railway infrastructure when it was designed. This field of research reveals the 'overprovision'or 'under-provision' ofrailways in different regions.

This type of work also allows us to discuss how important demographic factors are in the creation of the networkin comparison with other criteria of a political, economic or environmental nature. Railways have not always been built with reference to settlement, they also have to fit in with the physical geography (the first lines could not climb steep gradients, for example). Moreover, the network was created as the result of a set of decisions made by the State and/or private companies that aimed to satisfy a wide range of political and economic interests. Consequently, France and Spain built a radial network around the capital by which a centralizing authority asserted itself. Other countries,such as the Netherlands (Schmal, 2003), pursued a mercantile policy and designed a rail network that provided good port/hinterland links.

The second direction for research into historical demography sets out to identify and measure the effects of the railway on demographic concentration (Martí-Henneberg, 2005), urban growth and the hierarchy of cities.Several parameters are measured in this context: the demographic impact of rail as a result of population displacement (attraction, concentration, the structuring of space around stations, and the creation of rail hubs ${ }^{2}$ ).Studies are generally concerned with functional changes in the focal city and modification of the relationship between it and other cities, as a result of changes in its size or rank in the urban pyramid of the region. In this area, researchers have revealed the effects of demographic thresholds in terms of both density and city size. ${ }^{3}$

\footnotetext{
${ }^{2}$ An in-depth study of this topic has been conducted in Wales (Gregory andMartí-Henneberg, 2011) Also of note is Felis-Rota, Martí-Henneberg and Mojica(2012).

${ }^{3}$ Denise Pumain(1982) researched the spread of railways and the urban hierarchy in France between 1831 and 1911. Although urban growth was contemporary with the creation of the network, she detailed the correlations between the position of cities in the hierarchy (the rank-size rule), the way
} 


\subsection{Rail and the growth of cities: some convincing statistical demonstrations}

The findings of this interdisciplinary research, which combines history, demography and spatial analysis (Martí-Henneberg2008),clearly reveal the role played by rail networks in urban growth and highlight the influence of demographic changes on the development of railways.

The research generates three findings. First, railways tend to encourage geographical concentration, which leads to very major changes in the structure and hierarchy of the network of cities (Mojica and Martí-Henneberg, 2011). Railways primarily acted as a stimulus to the cities that were served early on, were located at junctions, and had populations of more than 10,000 inhabitants. However, a disaggregate analysis of the demographic variables casts doubt on the commonly held view that the railways hastened rural depopulation and the decline of village communities. As Schwartz et al. (2011b) explained'it is more the case that rail gave a second chance to rural communities with stable or restricted growth and opened up new cultural and economic horizons for them (for their agriculture, for the export of raw materials, and for timber or firewood)'[page 55]This being so, locations that could not be accessed by train became increasingly marginalised, so that rail did tend to exacerbate geographical inequalities. Finally, recent research has explained that line closures (from the beginning of the twentieth century) did not result in a general reduction in accessibility because the population was becoming concentrated in larger centres that retained their access to the network.

\subsection{Rail and migration: railways as one factor of rural desertification}

Another important topic is the link between the existence of the railway and urban-rural migration. The layman's view is that the railway, whose arrival coincided with the large-scale rural exodus, accentuated the process; however, thorough research involving geographically weighted regression ${ }^{4}$ shows the contrary. In reality, the more the accessibility of the rural zone by railway increased, the more net migration tended to fall. In France,the migratory dynamic was highly dependent on the station density of the canton and its distance from the

they are integrated with the network and the intensity of their growth. Her research shows the importance of the threshold of 10,000 inhabitants:'The larger the city, and the earlier the railway arrived there, the more important it became as a rail hub and the greater its growth'(p. 539). This work also shows that being positioned at the terminus or a junction is more advantageous than being simply an intermediate station.

${ }^{4}$ Geographically weighted regression (GWR) is an extension of a classical regression method that describes the relation between net migration and one or more explanatory factors. However, while regression produces an estimate of the relation between the variables in the entire study zone, GWR produces a set of estimates derived from the study of spatial units that are adjacent to each other. Thus, instead of giving a single, mean, result GWR produces an estimate of this relation for each spatial unit and shows the geographical variation between the variable and its explanatory factors. 
urban centre. ${ }^{5}$ Railways explain approximately 40 per centof migration, and statistical regression shows a wide range of interactions between demographic change, accessibility by rail, and the rural environment.

We therefore refer the reader to a large body of recently published research (Morillas, 2012)which emphasises that many methodological difficulties still remain:the availability of data, the stability of municipal boundaries and the historical continuity of statistical series all needattention in order to enhance the general quality of the databases (Siebert, 2004). The explanatory power of the regressions between demographic and railway data seem to be stronger during the periods when the network was being built and when major human migrations took place (generally, between 1860 and the 1920s) (Martí-Henneberg, 2011).In addition, few studies have examined the redrawing of national boundaries, the reconstruction of the network and the movements of populations (or peoples) that occurred in the aftermath of the Second World War (Carter, 1952; Mellor, 1992).

\section{Demographic changes and the efficiency of European railways}

\subsection{A caveat: the importance of not confusing demographic projection and long-term forecasting}

Let us now turn to the present. Much research has examined the effects of demographic and sociological change on the railway system, but little of this exploits all of the available data.Nevertheless, there are harmonised databases that use a fine-grained spatial scale (at municipal level with global coverage, as in the case of the work performed by Denise Pumain and FrançoisMoriconiEbrard(1997). These allow us to build spatial models of changes in the total population size and make demographic projections on the assumption that observed trends will continueinto the present and the medium-term, and provide information on the processes in question for the next 30 years or so. This data gives a general idea of the number of people who will be living in a given area. Theprojections highlight Europe's low overall demographic growth, and even a clear reduction in the total population, which is obviously unfavourable for the demand for passenger rail transport. Such projections are based on the continuation of the observed trend in the rate of natural increase (the birth rate minus the death rate), and a set of assumptions regarding the arrival of immigrants from outside Europe to make up the natural deficit.

\footnotetext{
${ }^{5}$ Multiple regression analysis shows that 31 per cent of the variation in the rate of growth between 1831 and 1911 depended on the importance of the city's railway junction, the date of the arrival of the railway and the city's size at that date' (Pumain 1982, pp. 539).
} 
Demographic projections extend dynamics that already exist,without adding new factors. However, they are based on assumptions about the net migration rate, which means that the process is effectively one of forecasting - that is,based on conjectures, which are often linked together to form contrasting narratives or scenarios. The future of railways necessarily involves both projections and scenarios: it requires us to make a forecast about migration, which is a topic that is obviously highly politically sensitive. Moreover, it requires us to work from demographic projections and to enrich these with socioeconomic characteristics: the propensity of future generations to travel, and the extent to which lifestyles will be mobile or immobile, which is in the domain of pure forecasting. Thus, in spite of the apparent freedom the forecasting narrative allows, such work tends to focus on the 27-member European Union,and rarely considersthe space formed by Europe and its neighbours (Banister and Givoni, 2013).It consequently remains very cautious on the topic of future migration.

\subsection{Demographic change and rail forecasting: benefits and limitations of some scenarios}

We have already mentioned the considerable uncertainty that reigns with regard to the ways in which societies and individuals may adapt to new demographic situations. However, we have no alternative but to try to link these masses of data, which are heterogeneous for the systems-dependent reasons described in the first section: the major models of mobility are influenced by the general economic climate and other major political (the distribution of wealth) and environmental (energy and climate) challenges.

The discipline of geographical forecasting, which is currently gaining prominence, occupies the middle ground between scienceand decision-making support for rail operators, and is responsible for two types of overarching narrative (Crozet, 2009). The first is the idea of 'contented mobility':in this scenario, Europe will open up its metropolises to a wave of immigration that will have the potential to mitigate the effects of population ageing on the jobs market and repopulate rural zones.The intensive use of high-speed transport systems (Gutiérrez et al., 1996)is essential for this scenario, as high-speed corridors, which will have become transnational, will connect capital cities and compete successfully with air transport, whose fuel will have become too expensive (Gutiérrez, 2001). Some lines will carry businessmen between banking and administrative centres, while others will carry tourists and individuals engaging in leisure activities, which will no longer be seasonal butdesynchronised.Some groups will even manage to 'live within the flows' (Cattan, Frétigny, 2012)and, using new technologies, construct their family lives and interpersonal relations 
around multiple homes, activities and national affiliations. For these individuals, the new hubs will be intermodal metropolitan stations containing a series of high-value-added business services, connected work areas and luxury hotels.

The other view, which provides a counterpoint to the first, is that of an ageing, impoverished Europe with ever-decreasing levels of mobility (Hoedemaeker2013; Harper, 2007). This is founded on the rapid increase in the percentage of the population aged over 65 years (30 per cent in 2060, compared with 17 per centtoday), the pandemic of obesity, which raises doubts about an increase in life expectancy in good health, increasing solitude and social fragmentation, lacklustre long-term economic growth, rising energy prices, the impoverishment of lower- and middle-income groups, and youth unemployment (Tetraplan A/S Copenhagen, 2007). These factors will combine to lower the total number of trips, as well as leading to a continuous and silent drop in the number of people going away on holiday,as has already been apparent for almost a decade (Schäfer, 2006). This scenario will have an impact on railway traffic by reducing the number of journeys and the profitability of railway undertakings, which become unable to adequately finance network maintenance.

We have no need to choose between these two meta-scenarios,as they are, above all, political in nature, and as such are simply intended to elicit reactions (Givoni, 2006). Essentially, these scenarios apply everywhere and are a-spatial, and, unlike those we shall describe below, take little account of concrete local factors and geographical differentiation.

\subsection{Demographic change and railway performance: a regional typology}

A second way of approaching the interaction between demographic forecasting and the performance of the railway system is to use spatial modelling (Kunz and Buiter, 2010). The principle here involves using geographical images to help us understandthis interaction. The images are produced not only by display systems that represent 'big data' but also narratives based on the statements of experts and varied conjectures. This type of approach allows us to identify three distinct geographical cases that are, to varying degrees,compatible with railway connectivity and accessibility.

AsEllwangerandGoerger (2001) explained,'high speed rail would be able to cope extremely well with a non-uniform reduction in density, with dense zones separated by deserted areas'[page 140].This quotation from a UIC study brings us to our first case, that of the enormous urbanised corridor that stretches from Italy to the Rhineland and contains the world's highest population densities, the most integrated metropolitan archipelagos and the highest density of railway lines, both per hectare and per thousand of the population. 
ThisEuropean 'heartland' is made up of a set of economically integrated (Euro zone) metropolisesthat are connected together within a robust HSR system with regular services. The challenges facing this heartland are to forecast increases in traffic, and to modernise in order to be able to cope with mass transit flows (Grasland et al., 2001). The fact that it is impossible for these urban mega-regions to become more urbanised is rarely mentioned (Belgium already has an urbanisation rate of 98 per cent (Vanoutrive et al., 2012)).In addition, this heartland contains the regions of Europe that will suffer the most from net population decline due to low fertility.

This central area is marked out from a system of marginal zones with distance-related gradation,and the presence of mountain and maritime barriers. The inner marginal zones consist of archipelagos of medium-sized cities, which often receive little in the way of demographic and economic stimulation, for which the efficiency of railways has been brought into question (Taylor, 2005). The outermarginal zonescorrespond to non-metropolised rural regions, where the presence of railways is either a historical relic or the outcome of the need to travel through the area or change trains. The areas that contain cities are frequently located in a circle around the Rhineland (the north-eastern part of France, the Polish plain, and the Czech and Hungarian systems of cities (Kosinski-Leszek, 1971)), while the rural marginal zonesare largely empty and provide a location fortranscontinental routes (PortugalUkraine, Ireland-Mezzogiorno, the Baltic-Black Sea, etc.).

The influence of the centre-periphery model is evident in this research, from which one main factoremerges: the central position of the re-unified Germany (Buckwalter, 2005), the combination of its industrial and demographic power, the importance of its railways and the implementation of a model that is both centralised (a radial network around Berlin) and polycentric cities regularly dispalyed in a distance of an hour away from one another by train). Germany is also the heart of european railway system thanks to the grid structure of its network, with lines running east-west (from the northern range ports to Poland and Russia (Friebel et al., 2007)) and north-south (from Scandinavia to the Mediterranean through the Swiss and Austrian tunnels). These cartographic exercises demonstrate the real advantages that stem from a central position, but they run counter with other analyses that show the concentration of the population in the margins of Europe along the Atlantic and Mediterranean coastal corridors, which is in keeping with the globalisation of the economy and the emergence of city-state port models that are fully integrated within financial flows. ${ }^{6}$

\footnotetext{
${ }^{6}$ This internal segmentation of the national rail system means that it is difficult to picture the overall competitiveness of a national railway network (see Haywood, 2007; Lapsley,1984).
} 


\subsection{Sociodemographic variables and railway performance indicators}

Apart from these spatial typologies, which are clearly highly dependent on systems ofrepresentation, there are a certain number of studies (Ellwanger and Georger, 2001)that use demographic indicators to construct railway-performance models. These demographic indicators are not disconnected from the other key indicators of the profitability of railway companies, and always involve the four vital factors of low interest rates, improved services, acceptable rail access charges and dynamic demand (Beck et al., 2013). However, if we look uniquely at demographics, the trends that are identified are double-edged. These trends have the potential either to encourage or discourage general levels of travel, the use of railways (for intercity travel and in Metropolitan zones) and HSR (Francisco and MartíHenneberg, 2009).

On one hand, considering the lengthening of life in good health provides us with between 150 and 200 million travellers who could potentially use the train for their work-related and leisure trips. These cohorts, who are already alive, are used to travelling, but are also used to cars and using air travel for tourism. It is reasonable to suggest that providing services (in terms of locations, times and pricing) that suit the lifestyles of these people will encourage them to travel by train. Furthermore, we can assume that energy constraints will foster environmentally friendly travel strategies that will include metropolitan, intercity and HSR travel. The growth in tourist flows to European destinations, in particular from emerging countries, is another potential source of rail passengers, with the future number of international visitors estimated at 800 million (twice today's level)(UNWTO, 2010).

There are of course other demographic factors that are less favourable to the increase in travel in general, and railway travel and high-speed travel in particular. The value of this type of exercise is to discuss the way in which demography combines with performance indicators (Hooghiemstra et al., 1999) such as capacity and locations served, speeds and time savings, punctuality, the travel environment and the quality of the experience, additional commercial services, etc. (Beck et al., 2013).Thus, a given factor is not in itself either positive or negative,but rather is part of a strategic approach. Let us consider the example of the desynchronisation of working hoursand the rhythms of work and leisure. This factor appears to be favourable to the train. At the present time, the success of HSR depends on two contrasting types of use: business trips between Monday and Thursday and leisure trips at weekends. Interaction between the two travel purposes and their spread over the entire week has the potential either to increase passenger load factors or create friction (caused by one 
type of passenger interfering with the other, inappropriate fares, provision of incompatible services, etc.), which will reduce the quality of service (Caldas de Castro, 2007).

\section{Conclusion and outlook}

This chapter shows the value of taking into account the European level when attempting to understand the links between railways, settlement and urban growth. A number of key ideas emerge from this exercise. First, these links were built up over a long period of time, and they have not only shaped a considerable diversity of geographical systems, but also constructed very powerful representations that still have a strong influence on debates on the efficiency of rail transport. Next, we have shown that the interaction between railways and demographic change is extremely dynamic, as the two have evolved together over decades, with periods of rapid readjustment and differences in both the chronology and nature of changes between one country or one region and another.Finally, knowledge about the future is vital for the rail sector, as it takes approximately 10 years to introduce new rolling stock and at least 20 to design and build a high speed line.In spite of its faults and weaknesses, we therefore still need forecasting (De Palma et al., 2010). However, it must be improved in two respects:first, greater transparency is required with regard to the construction and handling of the fundamental indicators and variables; andsecond, experts need to make greater use of geographic information systems in models that analyse the performance, vulnerability and resilience of the railway system (Tschopp et al., 2003) in order to promote a more geographicallybased approach.

\section{References}

Banister D. andGivoni, M.(2013), 'High speed rail in the EU 27: trends, time, accessibility and principles', Built Environment, 39 (3), 324-323.

Banister, D. and Hall. P. (1993), 'The age of the train', Built Environment,19 (34), 156-162.

Beck,A., Bente,H. and Schilling,M. (2013), Railway Efficiency, Discussion Paper,International Transport Forum, 2-4 May 2012 Leipzig

BuckwalterD.W. (2005), 'Transportation regions and the eastward integration of Europe', TijdschriftvoorEconomische en SocialeGeografie,,96 (1), 31-47.

Caldas de Castro, M. (2007), 'Spatial demography: an opportunity to improve policy making at diverse decision levels', Population Research and Policy Review,26 (5/6), 477-509. 
Caron, F. (2005), Histoire des chemins de fer en France. Paris: Fayard.

Carter J.P. (1952), 'The German railways an analysis of economic adaptation', Land economics, 28 (4), 307-317.

CattanN. andFrétignyJ-B.(2011), 'Les portesd'entrée de la France et les systèmesterritoriaux de flux,des systèmesspatiaux en prospective',Territoires 2040, La Documentation française DATAR,4,67-84.

Chatelain,A. (1947), 'Démogéographie du grand troncferrésud-est (Paris-LyonMéditerranée)'Les Étudesrhodaniennes.,22(1-4), 35-82.

Claval, P. (2000), 'The European system of capital cities', GeoJournal,,51 (1/2), 73-81.

Cobb, M.H. (2003), The Railways of Great Britain: A Historical Atlas. Cambridge: Cambridge University Press.

Crozet, Y.(2009), The Prospects for Inter-Urban Travel Demand: Three scenario families for inter-urban mobility in France to 2050, discussion paper No. 2009, 14 December, Joint Transport Research CentreMadrid.

De Palma, A., Proost, S. and Van der Loo, S. (2010),'Assessing transport investments towards a multi-purpose tool', Transportation ResearchPart B,44, 834-849.

del Río,E., Martí-Henneberg, J. andValentín, A.(2008), 'La evolución de la red ferroviaria en el ReinoUnido (1825-2000)', SegonCongrésCatalà de Geografia, 29-31.

Dieleman, F.M. andFaludi, A. (1998), 'Polynucleated metropolitan regions in Northwest Europe', European Planning Studies,6 (4), 365-375.

European Union, DG TREN, 2009, Un avenir durable pour les Transports vers un systèmeintégré, convivial et fondésur la technologie, 17 juin 2009, Brussels.

www.cre.org/img/uploads/piecejointe/filename/CEMR_future_of_transport_FR.pdf consulted june 30th 2014.

Ellwanger, G. andGeorger O. (2001), 'The impact of social and demographic changes on transport demand in Europe in the year 2030', Rail International, Association Internationale du Congrès des Chemins de Fer (AICCF), 6 (6-7), 139-147.

Felis-Rota, M.,MartíHenneberg, J. and Mojica, L.(2012), 'A GIS analysis of the evolution of the railway network and population densities in England and Wales, 1851-2000', EHA 2012 Annual Meeting, Vancouver, Canada, 21-23 September.

Friebel, G.,Guriev, S., Pittman, R.,Shevyakova, E. andTomová, A. (2007), 'Railroad restructuring in Russia and Central and Eastern Europe: one solution for all problems?', Transport Review,27 (3), 251-271.

Friendly, M., 2002, 'Visions and re-visions of Charles Joseph Minard', Journal of educational and behavioralstatistics, 27, 1, 31-51.

George, P.(1968), 'Chemin de fer et développementurbain', in CHF Commission d'HydrologieFluviale, Mélanges offerts à Maurice Pardé, Editions Ophrys, pp. 229-237. 
Givoni, M. (2006),'Speed rail: catalyst for european integration?'Transport Reviews26 (5), 593-612.

Grasland, C.,Peyrony, J. andPumain, D.(2001), Study Programme on European Spatial Planning, Final Report, BundesamtfürBauwesen und Raumordnung (BBR) Forschungen, Heft 103.2, accessed 31/05/2014 at http://www.nordregio.se/spespn/welcome.htm.

Gregory I. andMartí-Henneberg,J. (2011), 'The railways, urbanization, and local demography in England and Wales, 1825-1911', Social Science History(Summer), 34, 2, 199-228.

Gutiérrez, J. (2001),'Location, economic potential and daily accessibility: an analysis of the accessibility impact of the high-speed line Madrid-Barcelona-French border', Journal of Transport Geography9, 229-242.

Gutiérrez, J., González, R. and Gómez, G. (1996),'The European high-speed train network, predicted effects on accessibility patterns',Journal of Transport Geography4, 227238.

Hall, P. and Banister, D.(2013), 'High speed rail: Shrinking spaces, shaping places', Built Environment, 39 (3), 321-323.

Harper S.(2007), The Implications of an Ageing Population for the Railway :Scoping Research on Ageing for Passengers and the Railway Workforce, Rail Safety and Standards Board Ltd. 2008 research programme, London, March 2008.

Haywood, R. (2007),'Britain's national railway network: fit for purpose in the 21st century?' Journal of Transport Geography15, 198-216.

Hoedemaeker,M. 2013, Future mobility scenarios for older people 2020 to 2050, in Last report of the Project GOAL Transports needs for an ageing society, Vienna, september 30th 2013, consulted the 30/06/2014 at www;goal-project.eu

Hooghiemstra, J.S., Kroon, L.G., Odijk,M.A., Salomon, M. andZwaneveld,P.J. (1999), 'Decision support systems support the search for win-win solutions in railway network design', Interfaces, ,29 (2), 15-32.

Jensen, A. andRicharson, T.(2007), 'New region, new story: imagining mobile subjects in transnational space', Space and Polity,,11 (2), 137-150.

Juillard, E. (1971)‘Croissanceurbaine et accessibilité des villes', Revue de Géographie de l'Est, 3-4, (43), 231-245.

KosinskiLeszek A. (1971), 'Geography of population settlements in East Central Europe', Annals of the Association of American Geographers, 61 (3), 599-615.

Kunz, A. andBuiter, H. (2010),'Digital atlas on European Communications and Transport European Communications and Transport Infrastructures: Performance and Potentials, 1825-2000, A Digital Atlas', accessed on may 30th 2014 at: http://www.atlas-infra.eu. 
Labasse, J.(1945), 'Chemin de fer et Urbanisme', Les Étudesrhodaniennes, ,20(1-2), 121-123. Lalanne, L.(1863), 'Essaid'unethéorie des réseaux de chemins de ferfondéesurl'observation des faits et sur les loisprimordiales qui président au groupement des populations', Comptesrendushebdomadaires de l'Académie des Sciences, 50, 206-210.

Lapsley,I. (1984), 'Reconstructing British Rail: in search of a profitable railway',Managerial and Decision Economics, 5 (1), 32-48.

Martí-Henneberg, J. (2005), 'Empirical evidence of regional population concentration in Europe (1870-2000)' Population. Space and Place 11, 269-281.

Martí-Henneberg, J,. 2008, ‘European Science Foundation initiative (Eurocores) project'Water, Road and Rail: The Development of European Waterways, Road and Rail Infrastructures: A Geographical Information System for the History of European Integration (1825-2005)' http://web.udl.es/dept/geosoc/europa/in/presentacio.html'consultedjune 30th 2014.

Martí-Henneberg, J. (2011), 'Geographical information systems and the study of history', Journal of Interdisciplinary History,42 (1), 1-13.

Martí-Henneberg, J. (2013), 'European integration and national models for railway networks (1840-2010)', Journal of Transport Geography, 26, 126-138.

Mellor, R.(1992),'Railways and German Unification'Geography,,77 (3), 261-264.

Merger, M. and, Polino, M.-N. (Eds.), 20 (2004), COST 340.Towards a European Intermodal Transport Network: Lessons from History. A Critical Bibliography. Paris: AHICF.

Mojica, L. andMartí-HennebergJ., 'Railways and Population Distribution: France, Spain, and Portugal, 1870-2000', EHA 2012 Annual Meeting, Vancouver, Canada, September 2123.

Morillas, M. (2012), 'Creation of a geo-spatial database to analyse railways in Europe (18302010). A historical GIS approach'. Journal of Geographic Information Systems,4 (2), 176-187.

O'Brien, P.K. (1983), Railways and the Economic Development of Western Europe 18301914. London: Macmillan.

Pumain, D.(1982), 'Chemin de fer et croissanceurbaine en France au XIXe siècle',Annales de Géographie,507 (September-October),529-550.

Pumain, D., Moriconi-Ebrard, F., 1997, City size distributions and metropolisation, GeoJounrla, 43, 4, 307-394.

Ribeill, G. 1986), 'Au temps la révolutionferroviaire:L'utopiqueréseau'Cahier/GroupeRéseaux,5, 48-59.

Ribeill, G.(1989), 'Lalanne et la théorie des réseaux de chemins de fer' Flux, special issue, 45-56. 
Robinson,A H. (1967), 'The thematicmaps of Charles Joseph Minard', Imago Mundi, The international Journal for the History of Cartography, 21, 1, 95-108.

Roth, R.(2003), 'Interactions between railways and cities in nineteenth century Germany: some case studies', in Roth R. andPolino M.N., The City and the Railway in Europe.Ashgate Editions,, Burlington, pp. 3-28.

Schäfer, V. (2006), 'Long-term trends in global passenger mobility', in National academy of engineering, Frontiers of engineering,National Academies Press, Washington DC85-97 Schaeffer E., Pruvot A., (2010), Rail 2020, Accenture, Brussels, p. 3.

Schmal,H. (2003), 'Cities and railways in the Netherlands between 1830 and 1860', in Roth, R. andPolino, M.N., The City and the Railway in Europe.Ashgate Editions, Burlington, pp. 29-44.

Schnetzler,J. (1967), 'Le chemin de fer et l'espacefrançais', Revue de géographie de Lyon.,42(1). 81-118.

Schram, A. (1997), Railways and the Formation of the Italian State in the Nineteenth Century. Cambridge: Cambridge University Press.

Schwartz,R.M., Gregory,I.N. andMartí-Henneberg, J.(2011a), 'History and GIS: railways, population change, and agricultural development in late nineteenth century Wales', Journal of Interdisciplinary History,421 (Summer), 15-28.

Schwartz, R.M., Gregory, I.N. andThevenin, T. (2011b), 'Spatial history: railways, uneven development, and population change in France and Great Britain, 1850-1914'. Journal of Interdisciplinary History, 42 (1), 53-88.

Siebert, L. (2004), 'Using GIS to map rail network history'. Journal of Transport History,25 (1), 84-104.

Silveira, L., Alves, D., Lima, N., Alcantara, A. andPuig, J. (2011), 'Population and railways in Portugal, 1801-1930', Journal of Interdisciplinary History,42 (1), 29-52.

Steen Petersen, M.and Sessa, C. (coord.) (2007), 'TRANSvisionsReport on Transport Scenarios with a 20 and 40 Year Horizon', Final Report, March 2009.Tetrapan, Copenhaguen. Consulted on june 30th 2014, at www.81.47.175.201/flagship/attachments/2009_02_transvisions_report.pdf

Tapiador FJ. and Martí-Henneberg, J. (2009), Stations: Potential economic impacts of technological and organizational innovations in intermodal access to major passenger terminals, International Transport Research Symposium, Discussion Paper No. 2009-27, Madrid, November, 15th.

Taylor, Z. (2005), 'Railway closures to passenger traffic in Poland and their social consequences', Journal of Transport Geography, 14, 135-151. 
Tschopp, M.,Fröhlich, P. and Keller, K.W.A. (2003), 'Accessibiltity, spatial organisation and demography in Switzerland through 1920 to 2000: First Results', Conference paper STRC 2003 Session History \& Policy, 3rd Swiss Transport Research Conference, Monte Verità/Ascona,19-21 March.

Turnock, D. (1998), An Historical Geography of Railways in Great Britain and Ireland. Aldershot: Ashgate.

UNWTO, United Nations World Tourism Organisation, 2010, World tourism Barometer, Madrid, 8, 2, $64 \mathrm{p}$.

Vanoutrive,T., Van Malderen,L., Jourquin, B., Thomas, I.,Verhetsel, A. andWitlox, F.(2012), 'Rail commuting to workplaces in Belgium: a multilevel approach', International Journal of Sustainable Transportation, 6, 67-87 